\title{
Distribution of allele frequencies for genes associated with physical activity and/or physical capacity in a homogenous Norwegian cohort- a cross-sectional study
}

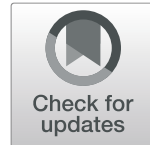

Sannija Goleva-Fjellet ${ }^{1 *}$ D, Anne Mari Bjurholt ${ }^{2}$, Elin H. Kure ${ }^{1,3}$, Inger Kristin Larsen ${ }^{4}$, Øyvind Støren ${ }^{2}$ and Mona Sæbø ${ }^{1}$

\begin{abstract}
Background: There are large individual differences in physical activity (PA) behavior as well as trainability of physical capacity. Heritability studies have shown that genes may have as much impact on exercise participation behavior as environmental factors. Genes that favor both trainability and participation may increase the levels of PA. The present study aimed to assess the allele frequencies in genes associated with PA and/or physical capacity, and to see if there is any association between these polymorphisms and self-reported PA levels in a cohort of middleaged Norwegians of Scandinavian descent ( $n=831$; mean age mean age ( \pm SD) $55.5 \pm 3.8$ years).

Results: The genotype distributions of the ACTN3 R577X, ACE I/D and MAOA UVNTR polymorphisms were similar to other populations of European descent. When comparing the genotype distribution between the low/medium level PA group (LMPA) and high level PA groups (HPA), a significant difference in ACTN3 577X allele distribution was found. The $X$ allele frequency was 10\% lower in the HPA level group $(P=0.006)$. There were no differences in the genotype distribution of the ACE I/D or MAOA uVNTR polymorphism. Education and previous participation in sports or outdoor activities was positively associated with the self-reported PA levels $(P \leq 0.001)$.

Conclusions: To the best of our knowledge, this is the first study to report association between ACTN3 R577X genotype and PA level in middle-aged Scandinavians. Nevertheless, the contribution of a single polymorphism to a complex trait, like PA level, is likely small. Socioeconomic variables, as education and previous participation in sports or outdoor activities, are positively associated with the self-reported PA levels.
\end{abstract}

Keywords: Genes, Polymorphism, ACTN3, Physical activity

\section{Background}

Physical activity (PA) is a complex behavior [1], influenced by both genetic and environmental variables [24]. The health effects of PA are well described [5-7], as are the negative consequences of inactivity [8-10]. Insufficient PA levels have been linked to an increased risk of many chronic diseases [11]. Physical inactivity is a modifiable risk factor meaning that increased PA may have a positive effect on several diseases, e.g. diabetes and

\footnotetext{
* Correspondence: sannija.goleva-fjellet@usn.no

${ }^{1}$ Department of Natural Sciences and Environmental Health, University of South-Eastern Norway, Gullbringvegen 36, 3800 Bø i, Telemark, Norway Full list of author information is available at the end of the article
}

hypertension [5, 12]. Recommendation for maintaining good health is aerobic PA for a minimum of $150 \mathrm{~min}$ per week at moderate intensity or a minimum of $75 \mathrm{~min}$ per week at high intensity [10]. Despite strong evidence for genetic influence on PA [1], it is complex and not yet fully understood.

There are large inter-individual differences in PA levels [13] and trainability [14, 15]. Genes influence response to exercise as well as intrinsic behavior like motivation for activity [16, 17]. Thus, genes that favor both trainability and participation may increase the levels of PA $[4,14]$. With increased age, heredity may have an even larger impact on exercise participation

(c) The Author(s). 2020 Open Access This article is distributed under the terms of the Creative Commons Attribution 4.0 International License (http://creativecommons.org/licenses/by/4.0/), which permits unrestricted use, distribution, and 
behavior [18]. Twin studies have shown that up to $62 \%$ of PA levels may be explained by genetic factors [4]. However, PA level is affected by the interaction of many genes, most of them with only a small effect each [13].

The two genes most studied in relation to trainability of cardiovascular traits [7, 19], physical function [20] and muscle strength [21] are $\alpha$-actinin-3 (ACTN3) and angiotensin-converting enzyme $(A C E)$. ACTN3 is a member of the alpha-actin binding protein family. It is predominately expressed in fast twitch muscle fibers [22]. The wild type RR genotype has been reported to be more common among athletes in sprint/power sporting disciplines [23, 24]. The bases for many previous studies have been ethnically highly heterogenous cohorts [25]. Around $18 \%$ of the European population are homozygous for the minor allele R577X polymorphism, a premature stop codon [23], with large differences in the minor allele frequency among populations. The frequency of the $\mathrm{X}$ allele covaries with the latitude gradient [26]. Absence of the $\alpha$ actinin-3 protein has been associated with a range of alterations in muscle function [27], including more efficient muscle metabolism [28], increased post-exercise muscle damage and risk of injuries [25]. The R577X polymorphism is one of only two known loss-of-function polymorphisms in humans known to have a selective advantage [27], it is more frequently observed in athletes participating in endurance disciplines $[23,24]$.

$A C E$ codes for the angiotensin-converting enzyme and plays a role in blood pressure regulation [29]. It also influences skeletal muscle metabolism [30] and thus aerobic capacity [31, 32]. Aerobic capacity has been shown to be an important determinant for PA levels [33]. The $A C E$ insertion/deletion (I/D) polymorphism is a length polymorphism, where a 287-bp Alu repeat is either present or absent [34]. The D allele is mostly associated with sprinting performance ability [35], while the I allele is associated with endurance performance ability $[35,36]$. Studies conducted on non-athletes have revealed that the $A C E$ I/D polymorphism may also influence responses to strength training [37]. Even though it has been suggested to influence the PA level [38, 39], the results are inconclusive [40].

In addition to genes influencing physiological exercise responses, genes altering PA motivation may also influence the PA level [16]. The dopaminergic system has been a subject to a number of studies on voluntary PA due to its role in reward systems and motor movement, $[16,41-43]$ and it has been shown to influence the inherent motivation to run in female mice [42].

Monoamine oxidase A $(M A O A)$ is one of the genes in the dopaminergic pathways [44] that have been found to influence sedentary behavior [16]. It codes for an enzyme involved in oxidation of neurotransmitters, especially, serotonin, norepinephrine and dopamine [45], and may thus play a role in behavior $[42,44]$. The $M A O A$ gene is located on the $\mathrm{X}$ chromosome and a variable number of tandem repeat sequence upstream from $M A O A$ (MAOA uVNTR) has been shown to influence the transcription levels of the enzyme [44]. Six alleles have previously been reported [46] with the major $M A O A$ allele 3 having lower transcriptional activity (TA) than the other common alleles 3.5 and 4 (high TA alleles) $[44,47]$ It has therefore been hypothesized that individuals with $M A O A$ high TA alleles degrade monoamine neurotransmitters more rapidly ultimately leading to lower PA levels [16]. Also the ACE gene may play a role in the dopaminergic pathways $[48,49]$, as the renin-angiotensin system, which the enzyme is a part of, and the dopaminergic system interacts [50]. Thus, $A C E$ might be involved in the neurobiological regulation of exercise motivation $[13,16]$. However, evidence for such relationships is still weak.

Identifying the role of genes and investigating their effect on PA behavior may contribute to further understanding of the large individual differences in PA behavior. Since many studies have been performed on either athletes, well-trained participants or patient groups, they generally have a low number of participants, and seldom represent the general population. In addition, there are large variations in allele frequencies between populations. In order to advance the knowledge, studies on larger and more homogenous cohorts are needed.

The functional ACTN3 R577X polymorphism has been associated with a range of different exercise and performance related phenotypes, but few studies, if any, have investigated its relation to PA levels. On the other hand, both $A C E \mathrm{I} / \mathrm{D}$ and $M A O A$ uVNTR polymorphisms have been studied in relation to PA phenotypes, however, the results have been inconsistent. Therefore, the aim of the present study was to assess $A C T N 3, A C E$ and $M A O A$ allele frequencies in a cohort of middle-aged Norwegians of mainly Scandinavian descent, and to investigate any associations between these genes and selfreported PA levels. In addition, the authors wanted to look for associations between socioeconomic variables, such as education and previous participation in sports or outdoor activities, and self-reported PA levels.

\section{Results}

\section{Demographics}

Blood samples and questionnaire data for 416 males and 415 females were available in this study. The mean age of the subjects was $55.5 \pm 3.8$ years. Participants were slightly overweight, as the mean BMI was $26.1 \pm 3.8$. However, the BMI in the HPA group was significantly lower than in the LMPA level group $(P=0.001$; Table 1$)$. The proportion of the cohort with higher education was $24.7 \%$. 
Table 1 Anthropometric data according to self-reported PA level

\begin{tabular}{|c|c|c|c|c|c|c|}
\hline \multirow[b]{2}{*}{ Variable } & \multicolumn{3}{|c|}{ Low/medium PA level } & \multicolumn{3}{|l|}{ High PA level } \\
\hline & All $(n=215)$ & Females $(n=82)$ & Males $(n=133)$ & All $(n=616)$ & Females $(n=334)$ & Males $(n=282)$ \\
\hline Age (y) & $55.8 \pm 3.8$ & $56.0 \pm 4.3$ & $55.6 \pm 3.5$ & $55.5 \pm 3.7$ & $55.3 \pm 3.7$ & $55.6 \pm 3.8$ \\
\hline Weight (kg) & $83.3 \pm 15.6$ & $76.6 \pm 15.8$ & $87.4 \pm 14.0$ & $76.9 \pm 12.9$ & $71.0 \pm 11.4$ & $83.8 \pm 11.1$ \\
\hline Height (cm) & $174.7 \pm 8.1$ & $167.7 \pm 5.0$ & $179.1 \pm 6.4$ & $172.5 \pm 8.6$ & $166.7 \pm 5.7$ & $179.4 \pm 6.0$ \\
\hline BMI $\left(\mathrm{kg} / \mathrm{m}^{2}\right)$ & $27.3 \pm 4.5$ & $27.3 \pm 5.5$ & $27.3 \pm 3.7$ & $25.7 \pm 3.5^{*}$ & $25.5 \pm 3.8^{*}$ & $26.0 \pm 3.0^{*}$ \\
\hline
\end{tabular}

Data are presented as mean \pm SD. $n$ - number of subjects; PA- physical activity; BMI- Body Mass Index. ${ }^{*} P \leq 0.009$ different from low/medium PA level

\section{Physical activity data}

Of the 831 participants, 25.9 and $74.1 \%$ reported LMPA and HPA, respectively. Females reported a significantly higher PA level compared to males $(P<0.01)$. Regular participation in sports or outdoor activities at a younger age was reported to be $51.7 \%$, and participation was higher among males (59.4\%) than females (44.0\%; $P<$ $0.01)$. Prior participation in sports and outdoor activities was positively associated with reported PA level later in life $(P<0.01)$. Similarly, higher education was positively associated with higher PA levels $(P<0.01)$.

\section{Genotype and allele frequency distribution for $A C E$, ACTN3 and MAOA}

Out of the 831 participants, 822 were successfully genotyped for the $A C T N 3,721$ for the $M A O A$ and 616 for the $A C E$ gene. For the $A C E$ gene, $24.5 \%(n=151)$ were homozygous for the D allele, $52.6 \%(n=324)$ were heterozygous, and $22.9 \%(n=141)$ were homozygous for the I allele (Table 2). Allele frequencies for the $A C E$ gene were 50.8 and $49.2 \%$ for the D and I allele, respectively. Genotype distribution for the ACTN3 gene was $30.8 \%$ $(n=253), 50.5 \%(n=415), 18.7 \%(n=154)$ for the RR, RX and XX genotype, respectively (Table 2). The frequency for the $\mathrm{R}$ allele was 56.0 , and $44.0 \%$ for the $\mathrm{X}$ allele. The observed genotype frequencies were in HWE for all genotypes. Genotype frequencies did not differ significantly between male and female subjects for either $A C T N 3$ R577X or $A C E \mathrm{I} / \mathrm{D}$ polymorphisms. For the $M A O A$ uVNTR polymorphism, five alleles were found: 2, 3, 3.5, 4 and 5 repeat alleles. Frequencies of the rare alleles were as follows: allele 2 was found in one heterozygous female; allele 5 in one hemizygous male and four heterozygous females; allele 3.5 in two hemizygous males and seven heterozygous females (1\%). Common allele frequencies were 38.6 and $61.4 \%$ for the alleles 3 and 4 , respectively. The observed heterozygosity for the common alleles was $42.5 \%$.

The ACTN3 X allele frequency was $10.0 \%$ lower in individuals with HPA than those with LMPA level

Table 2 Genotype distribution for the ACTN3, ACE and MAOA gene according to PA level

\begin{tabular}{|c|c|c|c|c|c|c|}
\hline \multirow[b]{2}{*}{ Genotype } & \multicolumn{3}{|c|}{ Low/medium PA level } & \multicolumn{3}{|l|}{ High PA level } \\
\hline & All $(n=215)$ & Females $(n=82)$ & Males $(n=133)$ & All $(n=616)$ & Females $(n=334)$ & Males $(n=282)$ \\
\hline \multicolumn{7}{|l|}{ ACTN3 } \\
\hline Total (n) & 214 & 82 & 132 & 608 & 330 & 278 \\
\hline $\mathrm{RR}$ & $23.4 \%^{*}$ & $28.0 \%$ & $20.5 \%$ & $33.4 \%^{*}$ & $34.2 \%$ & $32.4 \%$ \\
\hline $\mathrm{RX}$ & $58.9 \%^{*}$ & $57.3 \%$ & $59.8 \%$ & $47.5 \%^{*}$ & $47.0 \%$ & $48.2 \%$ \\
\hline$X X$ & $17.8 \%$ & $14.6 \%$ & $19.7 \%$ & $19.1 \%$ & $18.8 \%$ & $19.4 \%$ \\
\hline \multicolumn{7}{|l|}{$A C E$} \\
\hline Total (n) & 161 & 65 & 96 & 455 & 250 & 205 \\
\hline DD & $25.5 \%$ & $29.2 \%$ & $22.9 \%$ & $24.2 \%$ & $26.4 \%$ & $21.5 \%$ \\
\hline ID & $52.8 \%$ & $46.2 \%$ & $57.3 \%$ & $52.5 \%$ & $52.8 \%$ & $52.2 \%$ \\
\hline$\|$ & $21.7 \%$ & $24.6 \%$ & $19.8 \%$ & $23.3 \%$ & $20.8 \%$ & $26.3 \%$ \\
\hline \multicolumn{7}{|l|}{ MAOA } \\
\hline Total (n) & 187 & 70 & 117 & 534 & 290 & 244 \\
\hline Low TA ${ }^{1}$ & $29.4 \%$ & $14.3 \%$ & $38.5 \%$ & $27.7 \%$ & $15.2 \%$ & $42.6 \%$ \\
\hline High $\mathrm{TA}^{2}$ & $55.1 \%$ & $44.3 \%$ & $61.5 \%$ & $49.1 \%$ & $42.1 \%$ & $57.4 \%$ \\
\hline Heterozygotes $^{3}$ & $15.5 \%$ & $41.4 \%$ & - & $23.2 \%$ & $42.8 \%$ & - \\
\hline
\end{tabular}

Data are presented as frequency and percentages. $n$ - number of subjects, TA- transcriptional activity genotype. ${ }^{1} 3$-repeat allele male carriers and female homozygotes; ${ }^{2}$ 3.5- or 4-repeat allele male carriers and female homozygotes or heterozygotes; ${ }^{3}$ females only; ${ }^{*} P<0.01$ difference in $A C T N 3$ genotype distribution between low/medium and high PA level 


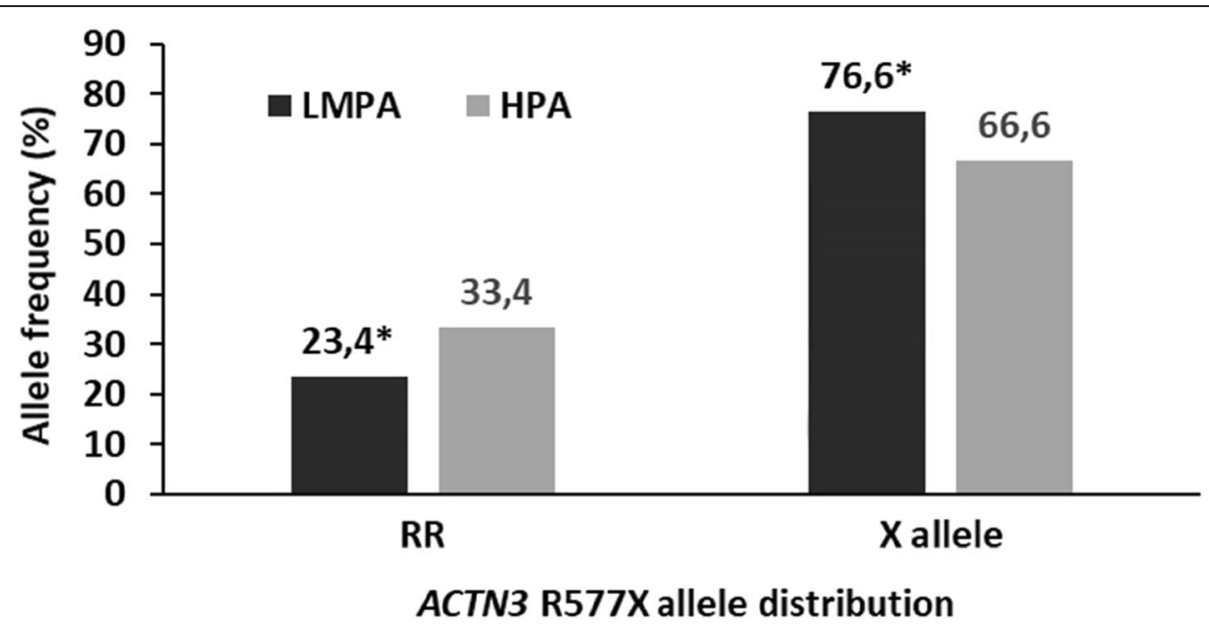

Fig. 1 ACTN3 R577X allele distribution differences between the low/medium and high physical activity groups. *significantly different from the high PA level group $(P=0.006)$. LMPA-low/medium physical activity group; HPA- high physical activity group

$(P=0.006$, Fig. 1$)$. When stratified by sex, significant difference in the $\mathrm{X}$ allele was only seen in males $(P=$ 0.013).

No associations were found between the ACE I/D (Fig. 2) or MAOA uVNTR (Fig. 3) polymorphisms and the PA level (Table 2).

\section{Logistic regression models}

Gender was found to significantly influence the likelihood of belonging to one of the two PA level groups, i.e. either to LMPA or to HPA level group $(P<0.001$; Table 3$)$. Males were less likely (OR: 0.47 ) to belong into the HPA level group compared to females. The BMI was more likely to be lower among subjects in the HPA level group compared to the LMPA level group counterparts $(p<0.01$; OR = 0.92). Education level showed a statistically significant association $(P<0.01)$ with the PA level. Participants having completed higher education were 2.2 times more likely to belong to the HPA group than the participants with secondary (or lower) education level. Also, subjects who participated in sports/outdoor activities earlier in life were 1.8 times more likely to belong to the HPA level group compared to those that had not $(P<0.01)$.

In the second logistic regression model, the genotype data were added to the socioeconomic factors tested previously. Those socioeconomic variables that contributed significantly to the PA level, remained significantly associated in the second model (Table 4). In addition, the ACTN3 R577X polymorphism was significantly associated with the PA levels $(P<0.01)$. Subjects with the RX genotype were more likely to belong to the LMPA level group $(P=0.001 ; \mathrm{OR}=0.43)$ compared to the $\mathrm{RR}$

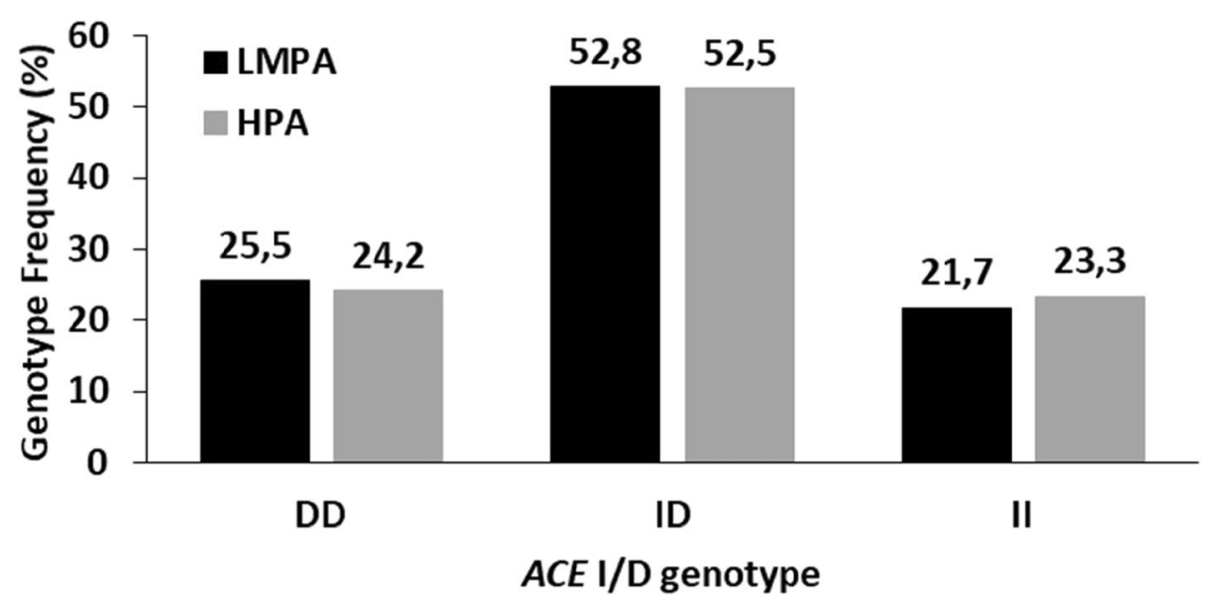

Fig. 2 ACE I/D genotype distribution in the low/medium and high physical activity groups. LMPA-low/medium physical activity group; HPA- high physical activity group 

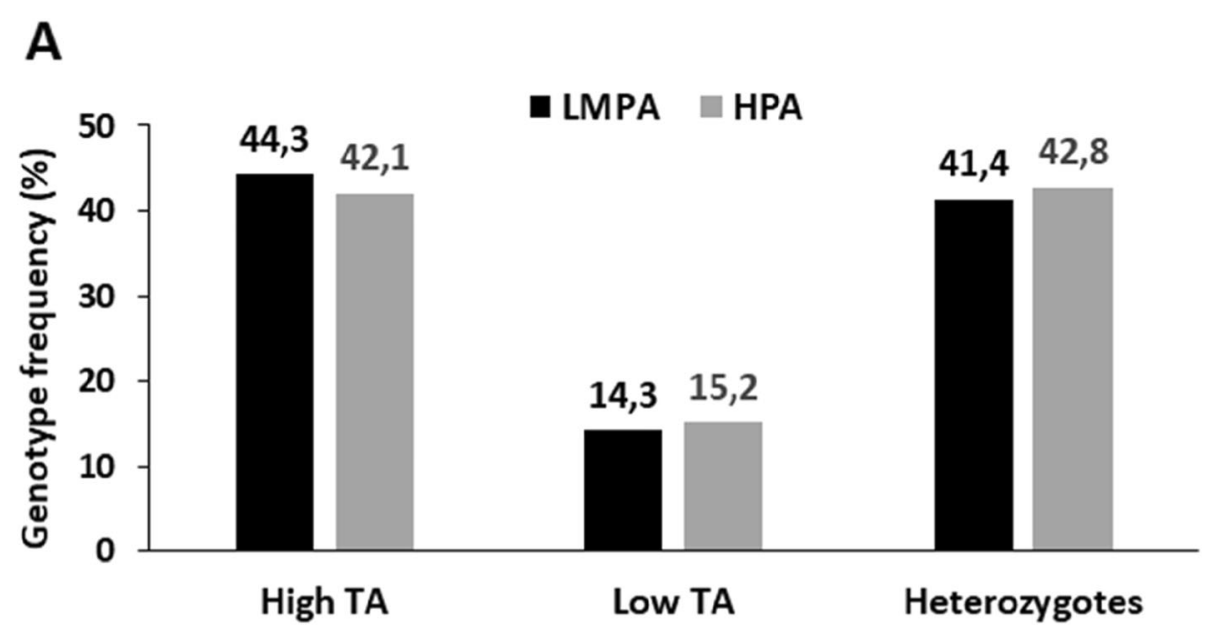

B

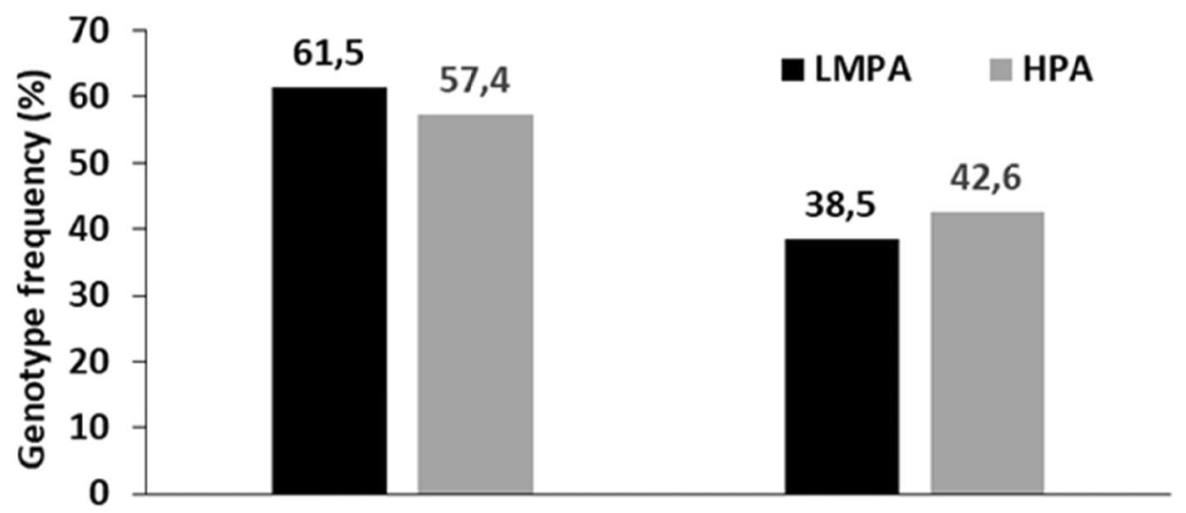

High TA

Low TA

Fig. 3 MAOA uVNTR genotype distribution in the low/medium and high physical activity groups among female (a) and male (b) participants. a TA- transcriptional activity genotype. Low TA represents 3-repeat allele homozygotes; High TA represents 3.5- or 4-repeat allele homozygotes and heterozygotes carrying one of each high TA alleles; heterozygotes- carriers of one low TA and one high TA alleles. b TA- transcriptional activity genotype. Low TA represents 3-repeat allele hemizygotes; High TA represents 3.5- or 4-repeat allele hemizygotes

Table 3 Variables entered on step 1: gender, age, BMI, education (2 categories) and participation in sports/outdoor activities earlier in life (2 categories)

\begin{tabular}{|c|c|c|c|c|c|c|c|c|}
\hline \multirow{2}{*}{$\begin{array}{l}\text { Variables included in } \\
\text { the equation }\end{array}$} & \multirow[t]{2}{*}{ B } & \multirow[t]{2}{*}{ S.E. } & \multirow[t]{2}{*}{ Wald } & \multirow[t]{2}{*}{ df } & \multirow[t]{2}{*}{ Sig. } & \multirow[t]{2}{*}{$\operatorname{Exp}(B)$} & \multicolumn{2}{|c|}{ 95\% C.I.for EXP(B) } \\
\hline & & & & & & & Lower & Upper \\
\hline Gender (Male/Female ${ }^{\text {r.c. }}$ ) & -0.753 & 0.205 & 13.513 & 1 & 0.000 & 0.471 & 0.315 & 0.704 \\
\hline Age & -0.035 & 0.027 & 1.731 & 1 & 0.188 & 0.965 & 0.915 & 1.018 \\
\hline $\mathrm{BMl}$ & -0.067 & 0.026 & 6.791 & 1 & 0.009 & 0.935 & 0.889 & 0.983 \\
\hline Education (Higher/Secondary ${ }^{\text {sr.c.) }}$ & 0.805 & 0.263 & 9.358 & 1 & 0.002 & 2.236 & 1.335 & 3.745 \\
\hline Sports earlier in life (Yes/No ${ }^{r . c}$ ) & 0.599 & 0.203 & 8.702 & 1 & 0.003 & 1.821 & 1.223 & 2.711 \\
\hline Constant & 4.080 & 1.723 & 5.606 & 1 & 0.018 & 59.173 & & \\
\hline
\end{tabular}

Significant values $(p<0.05)$ are indicated in bold; ${ }^{\text {r.c. }}$ - reference category; ${ }^{5}$ - Secondary education or lower 
Table 4 Variables entered on step 2: gender, age, BMI, education (2 categories), participation in sports/outdoor activities earlier in life (2 categories), ACE I/D polymorphism (3 categories), ACTN3 R577X (3 categories) and MAOA uVNTR (3 categories)

\begin{tabular}{|c|c|c|c|c|c|c|c|c|}
\hline \multirow{2}{*}{$\begin{array}{l}\text { Variables included in the } \\
\text { equation }\end{array}$} & \multirow[t]{2}{*}{ B } & \multirow[t]{2}{*}{ S.E. } & \multirow[t]{2}{*}{ Wald } & \multirow[t]{2}{*}{ df } & \multirow[t]{2}{*}{ Sig. } & \multirow[t]{2}{*}{$\operatorname{Exp}(B)$} & \multicolumn{2}{|c|}{ 95\% C.I.for EXP(B) } \\
\hline & & & & & & & Lower & Upper \\
\hline Gender (Male/Female $e^{\text {r.c. }}$ ) & -0.769 & 0.253 & 9.218 & 1 & 0.002 & 0.464 & 0.315 & 0.704 \\
\hline Age & -0.029 & 0.027 & 1.134 & 1 & 0.287 & 0.971 & 0.915 & 1.018 \\
\hline BMl & -0.071 & 0.026 & 7.252 & 1 & 0.007 & 0.932 & 0.889 & 0.983 \\
\hline Education (Higher/Secondary ${ }^{\text {s.c.c.) }}$ & 0.843 & 0.267 & 9.944 & 1 & 0.002 & 2.324 & 1.335 & 3.745 \\
\hline Sports earlier in life (Yes/No ${ }^{\text {r.c. }}$ ) & 0.643 & 0.207 & 9.635 & 1 & 0.002 & 1.902 & 1.223 & 2.711 \\
\hline ACE (all genotypes) & & & 0.611 & 2 & 0.737 & & & \\
\hline$A C E\left(I D / D D^{r . c .}\right)$ & 0.183 & 0.248 & 0.545 & 1 & 0.461 & 1.201 & 0.738 & 1.953 \\
\hline$A C E\left(I / / D D^{r . c .}\right)$ & 0.188 & 0.297 & 0.402 & 1 & 0.526 & 1.207 & 0.675 & 2.16 \\
\hline ACTN3 (all genotypes) & & & 11.473 & 2 & 0.003 & & & \\
\hline ACTN3 (XX/RR'.C. $)$ & -0.491 & 0.322 & 2.325 & 1 & 0.127 & 0.612 & 0.326 & 1.15 \\
\hline ACTN3 (RX/RR.C.) & -0.843 & 0.251 & 11.268 & 1 & 0.001 & 0.430 & 0.263 & 0.704 \\
\hline MAOA (all genotypes) & & & 0.777 & 2 & 0.678 & & & \\
\hline MAOA (Low TA/High TA $A^{\text {r.c. }}$ ) & 0.211 & 0.242 & 0.758 & 1 & 0.384 & 1.235 & 0.768 & 1.987 \\
\hline MAOA (Heterozygotes/High TA ${ }^{\text {r.c. }}$ ) & 0.089 & 0.317 & 0.079 & 1 & 0.778 & 1.093 & 0.588 & 2.035 \\
\hline Constant & 4.816 & 1.719 & 7.852 & 1 & 0.005 & 123.475 & & \\
\hline
\end{tabular}

Significant values $(p<0.05)$ are indicated in bold; ${ }^{\text {r.c }}$.- reference category; ${ }^{\$}$ - Secondary education or lower

genotype subjects. Neither $A C E$ I/D nor $M A O A$ uVNTR polymorphism showed a significant association with the PA levels.

\section{Discussion}

Allele frequencies for the ACTN3 R577X and the ACE I/ $\mathrm{D}$ polymorphisms has been reported to be highly variable between different ethnic groups, and the $\mathrm{X}$ allele has previously been reported to be much more common in Japanese (55\%) [51] than it is in Kenyans (9\%) [52]. Prevalence of the ACTN3 X allele in the present study was similar to populations of European descent, with around $45 \%$ of individuals being carriers of the minor allele [23].

The frequency distributions for the $A C E$ alleles in the present study are also in line with other populations of European descent [30] i.e. $25-50 \%$ - 25\% for the II, ID and DD alleles respectively. For the ACE I/D polymorphism, distribution of the D allele ranges from $10 \%$ for the D allele in Samoans [53], to around 60\% in African Americans [54]. Genotype frequencies in other studies on Norwegian subjects were comparable with the frequencies in the present study $[55,56]$. However, in one of the studies, the DD genotype was reported to be more prevalent than in other European populations. This is likely due to the preferential amplification of the $\mathrm{D}$ allele in heterozygotes, leading to mistyping of some heterozygotes as homozygotes for D allele [57]. That particular study did not used the insertion-specific primers to avoid mistyping of the ID genotype. The large variations in allele frequencies among different ethnicities is important to take into account when doing candidate gene studies [58]. Thus, analyzing homogenous cohorts [54], or accounting for the stratification [58] may improve study power. For the MAOA uVNTR polymorphism the allele frequencies were similar to those previously observed in Europeans [44, 47].

The present study found differences in the ACTN3 R577X allele distribution between the LMPA and the HPA level group. The logistic regression model indicated that the RX allele carriers were more likely to belong to the LMPA level group compared to the RR counterparts. Furthermore, individuals reporting HPA demonstrated higher frequency of the $\mathrm{R}$ allele compared to those reporting LMPA. Interestingly, when analyzed by gender, only males demonstrated significant differences in allele distributions between the two PA level groups. Although the authors have not found other studies reporting a relationship between the ACTN3 gene and PA levels in the general public, it has been suggested to be a potential candidate gene for PA behavior in mice models [13]. The ACTN3 R577X polymorphism has been linked to trainability of various cardiovascular traits [7, 19] which could, in turn, influence PA behavior [4]. Furthermore, the polymorphism has been associated with traits like sarcopenia [59], muscle function [51] and strength [60]. Previous research indicates that these may be important correlates of PA phenotypes [61-64]. Animal studies have shown changes in signaling and metabolism, among other things [27], which might help 
to explain the differences in phenotypes between the different genotypes.

Only few studies have been performed on ACE I/D polymorphism and PA levels in adults. Similarly to $\mathrm{Fu}-$ entes et al. [40], the present study could not find any relationship between the $A C E \mathrm{I} / \mathrm{D}$ polymorphism and PA levels, although some previous studies have found an association $[38,39]$.

The $M A O A \mathrm{uVNTR}$ polymorphism has a potential to be a candidate gene for influencing PA due to the phenotypic differences in transcriptional activity. Higher TA is expected to lead to higher monoamine oxidase activity and thus lower levels of monoamine neurotransmitters [44]. This, in turn, may lead to different PA level phenotypes [16]. However, the present study could not confirm the findings of Good et al. [16] who observed higher levels of PA in girls homozygous for the low TA allele compared to the high TA allele counterparts. It is still unclear whether the high and low TA alleles influence the monoamine oxidase A enzyme activity in the brain, as Fowler et.al [65]. was not able to measure significant enzyme activity differences in brains of healthy male participants.

Results from the present study showed a strong association between the present PA level and PA at younger ages $(P<0.01)$. Education also correlated with PA levels in the present study $(\mathrm{P}<0.01)$. Both education level $[66$, 67], and PA activity level at younger ages [66, 68], have in previous studies been shown to correlate positively with present PA levels.

A large proportion of the present cohort reported high PA level (74\%). This could be, in part, due to the use of questionnaires as a method for determining the PA levels in the present study. Questionnaire-based methods have been shown to over or underestimate PA behavior compared to the objectively measured PA. The subjective nature of questionnaires may explain the large variation in PA levels observed between different studies [69]. Nevertheless, due to cost efficiency, questionnaires are often used in large epidemiologic studies, including genetic studies [1]. Another questionnaire-based study on a large European cohort of older subjects reported relatively low proportion of participants with no vigorous/moderate physical activity. The overall prevalence of inactivity in the cohort was reported to be $12.5 \%$, with the Scandinavian countries demonstrating some of the lowest rates, i.e. 4.9 and $7.5 \%$ in Sweden and Denmark, respectively [64].

The present cohort was randomly drawn from NORCCAP, a homogenous Scandinavian population study with a high attendance rate [70]. The data from the questionnaires allowed the authors to map the ethnicity of the participants. Out of the 831 participants, only two did not have grandparents of Scandinavian descent or lacked the information about ethnicity. The remaining 829 (99, $8 \%$ ) had grandparents of Scandinavian descent. According to Marchini, Cardon [71], a well-known problem with genetic association studies is the undetected population structure such as heterogeneous ethnicity. In the present study, the material may be regarded as ethnically homogenous based on the results from the questionnaires. This can be regarded as one of the strengths of the present study, as a homogenous cohort reduces the chances of both false positive results and failures to detect genuine associations [71]. A further stratification based on ethnicity was therefore not necessary or possible.

Although study population was overweight, the differences in the BMI between the LMPA and HPA groups may also indicate that the self-reported PA levels are reliable [72]. Increase in adiposity (BMI) has been reported to be the cause of decrease in PA levels, as opposed to being the consequence of inactivity $[43,73,74]$. The design of the present study would have been strengthened by including direct measurements of the PA levels to validate the questionnaire data [69].

\section{Conclusions}

The present study demonstrates a novel finding that the $\mathrm{X}$ allele of the ACTN3 gene is underrepresented among participants reporting high PA levels. Genotype data from the present study can be used as a control population in future intervention studies on subjects of European descent. Consistently with previous reports, PA levels in adulthood are associated with factors like education and participation in exercise or outdoor activities earlier in life.

\section{Methods \\ Participants}

Blood samples and self-reported PA data were available for 831 individuals from the cohort "Kolorektal cancer, Arv og Miljø (KAM)", a molecular epidemiological study partly based on the screening group of the Norwegian Colorectal Cancer Prevention Study (The NORCCAP study) in the county of Telemark, Norway [70, 75]. The study design, inclusion/exclusion criteria, participation rates and other relevant information about the NORCCAP study is described in Bretthauer, Gondal [70]. The study was approved by the Regional Medical Ethics Committee of South-Eastern Norway and the Data Inspectorate (REK 3087, S-98052 and S-98190), and is registered in Clinical Trials [76] with the identifier NCT00119912. All procedures performed in studies involving human participants were in accordance with the ethical standards of the institutional and/or national research committee, and with the 1964 Helsinki declaration and its later amendments or comparable ethical 
standards. Informed written consent was obtained from all individual participants included in the study. Only control subjects (polyp free or polyps with mild grade dysplasia) were included in the present study. Socioeconomic data, including education data, were available for all the subjects. Characteristics of the participants are presented in Table 1.

\section{Assessment of PA level}

PA data was obtained by questionnaire used in the KAM study [75]. The following questions had graded responses on weekly frequency of the activity: "In the last five years, have you walked or bicycled to or from work?", "Do you hike (cross country)?", "How often do you exercise for at least 20 minutes?". Questions "If you exercise, do you perspire?" and "Were you regularly participating in sports or outdoor activities at a younger age?" were dichotomous.

Since the demand for energy differs between various types of activities [77, 78], the different activities were scaled as for example: Hiking $=1$ (used as reference, and representing moderate to vigorous intensity), Walking/ bicycling $=0.5$ (representing low to moderate intensity), Exercise $=1.5$ (representing vigorous intensity). By summing the frequencies per week of the scaled activities, each person achieved an activity score. The American College of Sports Medicine (ACSM) has recommended moderate-intensity cardiorespiratory exercise training for at least $30 \mathrm{~min}$, at least five days per week, or at least 20 min of vigorous-intensity cardiorespiratory exercise training for at least three days per week, or a combination of the two training modalities [79]. The activity score of 3 in the present study thus represents the minimum for accomplishing the ACSM physical activity recommendations. For example, a person performing exercise training of $45 \mathrm{~min}$ two times per week, or hiking three times per week, or performing walking or cycling six times per week, will reach the activity score 3 . Therefore, participants who achieved a score under 3 were defined as inactive or untrained (possessing LMPA) and those who achieved a score $\geq 3$ was defined as active/ trained (possessing HPA). These PA level groups were assessed for any associations with the ACE I/D, ACTN3 R577X and MAOA uVNTR genotypes, as well as for relationships with gender, education level and previous participation in sports or outdoor activities.

\section{DNA collection and genotyping}

The genomic DNA was extracted from venous EDTA blood stored at $-20^{\circ} \mathrm{C}$ by using a salting out procedure [80] with minor modifications [75].

The $A C E \mathrm{I} / \mathrm{D}$ polymorphism was genotyped using the Eppendorf Mastercycler Gradient (Eppendorf AG, Germany). Each reaction mixture of $25.5 \mu \mathrm{l}$ contained
2\% DMSO, 1 x PCR buffer, $0.2 \mathrm{mM}$ dNTP, $2 \mathrm{mM} \mathrm{MgCl}$, $0.2 \mathrm{pmol} / \mu \mathrm{l}$ of each primer, $0.5 \mathrm{U} / \mu \mathrm{l}$ Taq polymerase, and $1 \mu \mathrm{l}$ of DNA $(\sim 100 \mathrm{ng})$. Forward and reverse primer were 5'-CTGGAGACCACTCCCATCCTTTCT-3' and 5'-GATGTGGCCAT-CACATTCGTCAGAT-3', respectively [34]. Initial denaturation at $95^{\circ} \mathrm{C}$ for $3 \mathrm{~min}$ was followed by 30 cycles of denaturation $\left(95^{\circ} \mathrm{C} ; 15 \mathrm{~s}\right)$, hybridization $\left(53^{\circ} \mathrm{C} ; 45 \mathrm{~s}\right)$ and extension $\left(72^{\circ} \mathrm{C} ; 30 \mathrm{~s}\right)$. After final elongation $\left(72^{\circ} \mathrm{C}\right.$; $\left.5 \mathrm{~min}\right)$ the PCR products were stored at $4{ }^{\circ} \mathrm{C}$. These were separated by $6 \%$ polyacrylamide gel electrophoresis (PAGE) for $30 \mathrm{~min}$ at $150 \mathrm{~V}$, and resulted in three possible outcomes (DD, ID and II).

The ACE I allele is often weakly amplified in heterozygotes. Samples with the DD genotype were therefore reanalyzed by using a different PCR reaction in order to avoid mistyping of heterozygotes as DD. Insertion specific forward primer 5'-TTTGAGACGGAGTCTCGCTC-3' and standard reverse primer [57] were used. Each reaction of $25.0 \mu \mathrm{l}$ contained $12.5 \mu \mathrm{l}$ AmpliTaq Gold ${ }^{\circ}$ PCR Master Mix (Thermo Fisher Scientific, Inc.; MA, USA), 5\% DMSO, $0.2 \mathrm{pmol} / \mu \mathrm{l}$ of each primer, and $\sim 100 \mathrm{ng}$ template DNA. PCR reaction conditions were as follows: initial denaturation at $95^{\circ} \mathrm{C}$ for $3 \mathrm{~min}$ followed by 30 cycles of denaturation $\left(92^{\circ} \mathrm{C}\right)$, hybridization $\left(61^{\circ} \mathrm{C}\right)$ and extension $\left(72{ }^{\circ} \mathrm{C}\right)$ for $1 \mathrm{~min}$ each. After final elongation $\left(72{ }^{\circ} \mathrm{C} ; 7\right.$ $\mathrm{min})$ the PCR products were visualized by $6 \%$ PAGE. Insertion specific PCR reaction yielded a $408 \mathrm{bp}$ long DNA fragment in carriers of the I-allele and no PCR product in DD subjects. 215 (25.8\%) samples yielded no genotype results ever after repeated PCR runs.

Genotyping of the ACTN3 R577X polymorphism was carried out with TaqMan ${ }^{\circ}$ SNP Genotyping Assay, assay ID C_590093_1 (Applied Biosystems ${ }^{\circ}$, CA, USA) on the StepOnePlus ${ }^{\mathrm{Tm}}$ Real-Time PCR System (Applied Biosystems ${ }^{\circ}$, CA, USA). Genotype calling was performed by StepOne Software v2.0. Each $15 \mu \mathrm{l}$ reaction genotyping mixture contained $8.44 \mu \mathrm{l}$ Genotyping Master Mix, $0.42 \mu \mathrm{l}$ Assay mix (40x), $6.33 \mu \mathrm{l}$ distilled $\mathrm{H}_{2} 0$ and $~ 150$ ng of DNA template. Reaction conditions were as follows: $30 \mathrm{~s}$ at $60^{\circ} \mathrm{C}$ was followed by initial denaturation stage for $10 \mathrm{~min}$ at $95^{\circ} \mathrm{C}$; denaturation at $95^{\circ} \mathrm{C}$ for $15 \mathrm{~s}$ followed by annealing at $60^{\circ} \mathrm{C}$ for $1 \mathrm{~min}$ in cycling stage with 40 cycles altogether; finally post read temperature was kept at $60^{\circ} \mathrm{C}$ for $30 \mathrm{~s}$. Nine samples (1.1\%) yielded no genotype results.

The MAOA promoter polymorphism was amplified by PCR followed by capillary electrophoresis on an Applied Biosystems 3130xl genetic analyzer using GeneMapper ${ }^{\circ}$ (Applied Biosystems ${ }^{\circ}, \mathrm{CA}$, USA) Software 5. Each $15 \mu \mathrm{l}$ reaction contained 5\% DMSO, 1x PCR buffer, $0.2 \mathrm{mM}$ dNTP, $2.5 \mathrm{mM} \mathrm{MgCl}, 0.4 \mathrm{mM}$ of each primer, $1 \mathrm{U} / \mu \mathrm{l}$ Taq polymerase. The PCR conditions were as follows: initial denaturation at $95{ }^{\circ} \mathrm{C}(2 \mathrm{~min})$ followed by 35 cycles 
of denaturation at $95^{\circ} \mathrm{C}(1 \mathrm{~min})$, annealing at $55.5^{\circ} \mathrm{C}(1$ min) and elongation at $72^{\circ} \mathrm{C}(2 \mathrm{~min})$, and a final elongation at $72{ }^{\circ} \mathrm{C}(5 \mathrm{~min})$. Primer sequences have been described earlier [44], and were as follows: a FAM labeled forward primer 5' -ACAGCCTGACCGTGGAGAAG-3' and a reverse primer 5'-GAACGGACGCTCCA TTCGGA-3'. 110 (13.2\%) samples yielded no results even after repeated PCR run.

In order to check for reproducibility for $A C E \mathrm{I} / \mathrm{D}$ and $M A O A$ uVNTR polymorphisms, approximately $10 \%$ of the samples were re-analyzed. In addition, those samples that yielded inconclusive results were re-run. They were excluded from further data analysis if the samples did not yield any genotype or if they remained inconclusive. For ACTN3 R577X, all samples were run as duplicates.

\section{Statistical analysis}

The material was tested for normality and corrected for multiple testing (Bonferroni method), where appropriate. Association between the BMI and PA level groups was analyzed by using two-tailed independent sample t-test. Pearson's Chi-square test $\left(x^{2}\right)$ was applied to test for the Hardy-Weinberg equilibrium (HWE) for the ACTN3 R577X, ACE I/D genotype, and the differences in categorical variables, including genotype and allelic frequencies between the PA level groups. MAOA genotypes were analyzed by dividing genotypes into groups, based on the TA of the alleles [44, 47]. Males carrying the 3repeat allele and homozygous females for the 3-repeat allele were grouped into low TA, while males carrying either 3.5- or 4-repeat alleles were grouped into high TA group. Similarly, females homozygous for either 3.5 or 4-repeat-alleles and females heterozygous for 3.5 or 4repeat-alleles were grouped into high TA group. Heterozygous females carrying one 3-repeat and either 3.5- or 4-repeat allele were placed into the heterozygous group. Individuals carrying the rare alleles were excluded from the analysis.

To test the contribution of socioeconomic factors (Gender, Age, BMI, Education, Participation in sports/ outdoor activities earlier in life) and genetic variables (ACTN3 R577X, ACE I/D and MAOA uVNTR genotypes) to the PA level, binomial logistic regression was used. For this purpose, two models were analyzed: 1 . socioeconomic factors only; 2 . socioeconomic and genotype data together. Odds ratio (OR) were calculated for the significant associations in the logistic regression. Significance was set at 0.05 for all tests. Results are presented as mean $\pm \mathrm{SD}$. All statistical analysis was performed in IBM SPSS Statistics, version 25 (Chicago, IL, USA).

\section{Abbreviations}

ACE: Angiotensin-converting enzyme; ACTN3: a-actinin-3; BMl: Body mass index; HPA: High physical activity; HWE: Hardy-Weinberg equilibrium;
KAM: «Kolorektal cancer, Arv og Miljø» study; LMPA: Low/medium physical activity; MAOA: Monoamine oxidase A; PA: Physical activity;

PAGE: Polyacrylamide gel electrophoresis; PCR: Polymerase chain reaction; TA: Transcriptional activity

\section{Acknowledgments}

Authors thank Andrew Jenkins for his contribution to the English proofreading. The authors would also like to thank the University of SouthEastern Norway Publication funds for providing the financial support to cover Article Processing Charges.

\section{Authors' contributions}

SGF carried out the genetic studies, interpreted the study results and drafted the manuscript, AMB converted the questionnaire responses to PA level scores, interpreted the study results and also drafted the manuscript, EHK, $I K L, M S$ and $\varnothing S$ participated in designing the study, interpreting the results, writing and supervising the writing of the manuscript. All authors have read and approved the final version of the manuscript, and agree with the order of presentation of the authors.

Funding

No funding was received.

\section{Availability of data and materials}

The datasets generated and/or analyzed during the current study are not publicly available due to Norwegian legislation but are available from the corresponding author on reasonable request.

\section{Ethics approval and consent to participate}

The Regional Medical Ethics Committee of South-Eastern Norway and the Data Inspectorate (REK 3087, S-98052 and S-98190) approved the study. All procedures performed in studies involving human participants were in accordance with the ethical standards of the institutional and/or national research committee. Informed written consent was obtained from all individual participants included in the study.

\section{Consent for publication}

Not applicable.

\section{Competing interests}

The authors declare that they have no competing interests.

\section{Author details}

${ }^{1}$ Department of Natural Sciences and Environmental Health, University of South-Eastern Norway, Gullbringvegen 36, 3800 Bø i, Telemark, Norway. ${ }^{2}$ Department of Sports, Physical Education and Outdoor Studies, University of South-Eastern Norway, Gullbringvegen 36, 3800 Bø i, Telemark, Norway.

${ }^{3}$ Department of Cancer Genetics, Institute for Cancer Research, Oslo

University Hospital-The Norwegian Radium Hospital, Oslo, Norway.

${ }^{4}$ Department of Registration, Cancer Registry Of Norway, Oslo, Norway.

Received: 12 April 2019 Accepted: 16 January 2020

Published online: 23 January 2020

References

1. Bray MS, Fulton JE, Kalupahana NS, Lightfoot JT. Genetic Epidemiology, Physical Activity, and Inactivity. Genet Mol Aspects Sport Performance. 2011:81-9.

2. De Moor MH, Liu YJ, Boomsma DI, Li J, Hamilton JJ, Hottenga JJ, et al. Genome-wide association study of exercise behavior in Dutch and American adults. Med Sci Sports Exerc. 2009;41(10):1887-95.

3. Lightfoot JT. Current understanding of the genetic basis for physical activity. J Nutr. 2011:141(3):526-30.

4. Stubbe JH, Boomsma DI, Vink JM, Cornes BK, Martin NG, Skytthe A, et al. Genetic Influences on Exercise Participation in 37.051 Twin Pairs from Seven Countries. PloS one. 2006;1(1):e22.

5. Bird SR, Hawley JA. Exercise and type 2 diabetes: new prescription for an old problem. Maturitas. 2012;72(4):311-6.

6. Ehsani AA, Martin WH 3rd, Heath GW, Coyle EF. Cardiac effects of prolonged and intense exercise training in patients with coronary artery disease. Am J Cardiol. 1982;50(2):246-54. 
7. Myerson SG, Montgomery HE, Whittingham M, Jubb M, World MJ, Humphries SE, et al. Left ventricular hypertrophy with exercise and ACE gene insertion/deletion polymorphism: a randomized controlled trial with losartan. Circulation. 2001;103(2):226-30.

8. Levine JA. Lethal sitting: homo sedentarius seeks answers. Physiology (Bethesda, Md). 2014;29(5):300-1.

9. McGuire DK, Levine BD, Williamson JW, Snell PG, Blomqvist CG, Saltin B, et al. A 30-year follow-up of the Dallas Bedrest and training study: I. effect of age on the cardiovascular response to exercise. Circulation. 2001;104(12): 1350-7.

10. World Health Organization. Global recommendations on physical activity for health. Geneva: World Health Organization; 2010.

11. Hallal PC, Andersen LB, Bull FC, Guthold R, Haskell W, Ekelund U, et al. Global physical activity levels: surveillance progress, pitfalls, and prospects. Lancet. 2012;380(9838):247-57.

12. Hagberg JM, Park JJ, Brown MD. The role of exercise training in the treatment of hypertension - an update. Sports Med. 2000;30(3):193-206.

13. Lightfoot JT. Can you be born a couch potato? The genomic regulation of physical activity. Exercise Genomics: Springer; 2011. p. 45-72.

14. Nicklas BJ. Heterogeneity of physical function responses to exercise in older adults: possible contribution of variation in the Angiotensin-1 converting enzyme (ACE) gene? Perspect Psychol Sci. 2010;5(5):575-84.

15. Sarzynski MA, Rankinen T, Bouchard C. Twin and Family Studies of Training Responses. 2011. In: genetic and molecular aspects of sport performance [internet]. Wiley-Blackwell.

16. Good DJ, Li M, Deater-Deckard K. A genetic basis for motivated exercise Exerc Sport Sci Rev. 2015;43(4):231-7.

17. Simonen RL, Rankinen $T$, Perusse $L$, Leon AS, Skinner JS, Wilmore JH, et al. A dopamine D2 receptor gene polymorphism and physical activity in two family studies. Physiol Behav. 2003;78(4-5):751-7.

18. Stubbe JH, Boomsma DI, De Geus EJ. Sports participation during adolescence: a shift from environmental to genetic factors. Med Sci Sports Exerc. 2005;37(4):563-70.

19. Deschamps $\mathrm{CL}$, Connors KE, Klein MS, Johnsen VL, Shearer J, Vogel HJ, et al. The ACTN3 R577X Polymorphism Is Associated with Cardiometabolic Fitness in Healthy Young Adults. PloS one. 2015;10(6):e0130644.

20. Pereira A, Costa AM, Leitao JC, Monteiro AM, Izquierdo M, Silva AJ, et al. The influence of ACE ID and ACTN3 R577X polymorphisms on lower-extremity function in older women in response to high-speed power training. BMC Geriatr. 2013;13:131.

21. Pereira A, Costa AM, Izquierdo M, Silva AJ, Bastos E, Marques MC. ACE I/D and ACTN3 R/X polymorphisms as potential factors in modulating exerciserelated phenotypes in older women in response to a muscle power training stimuli. Age. 2013;35(5):1949-59.

22. Mills $M$, Yang N, Weinberger $R$, Vander Woude DL, Beggs AH, Easteal S, et al. Differential expression of the actin-binding proteins, alpha-actinin-2 and -3, in different species: implications for the evolution of functional redundancy. Hum Mol Genet. 2001;10(13):1335-46.

23. Yang N, Garton F, North K. alpha-actinin-3 and performance. Med Sport Sci. 2009;54:88-101.

24. Ahmetov II, Egorova ES, Gabdrakhmanova LJ, Fedotovskaya ON. Genes and athletic performance: an update. Med Sport Sci. 2016;61:41-54.

25. Pickering C, Kiely J. ACTN3: more than just a gene for speed. Front Physiol. 2017:8:1080

26. Friedlander SM, Herrmann AL, Lowry DP, Mepham ER, Lek M, North KN, et al. ACTN3 allele frequency in humans covaries with global latitudinal gradient. PLoS One. 2013;8(1):e52282.

27. Lee FXZ, Houweling PJ, North KN, Quinlan KGR. How does a-actinin-3 deficiency alter muscle function? Mechanistic insights into ACTN3, the 'gene for speed'. Biochim Biophys Acta. 2016;1863(4):686-93.

28. Head SI, Chan S, Houweling PJ, Quinlan KGR, Murphy R, Wagner S, et al. Altered Ca2+ Kinetics Associated with alpha-Actinin-3 Deficiency May Explain Positive Selection for ACTN3 Null Allele in Human Evolution. PLoS genetics. 2015;11(1).

29. Coates D. The angiotensin converting enzyme (ACE). Int J Biochem Cell Biol. 2003;35(6):769-73

30. Jones A, Woods DR. Skeletal muscle RAS and exercise performance. Int Biochem Cell Biol. 2003:35(6):855-66.

31. Goh KP, Chew K, Koh A, Guan M, Wong YS, Sum CF. The relationship between ACE gene ID polymorphism and aerobic capacity in Asian rugby players. Singap Med J. 2009;50(10):997-1003.
32. Tamburus NY, Verlengia R, Kunz VC, Cesar MC, Silva E. Apolipoprotein B and angiotensin-converting enzyme polymorphisms and aerobic interval training: randomized controlled trial in coronary artery disease patients. Braz J Med Biol Res. 2018:51(8):e6944.

33. Novak CM, Escande C, Gerber SM, Chini EN, Zhang M, Britton SL, et al. Endurance capacity, not body size, determines physical activity levels: role of skeletal muscle PEPCK. PLOS One. 2009;4(6):e5869.

34. Rigat B, Hubert C, Corvol P, Soubrier F. PCR detection of the insertion/ deletion polymorphism of the human angiotensin converting enzyme gene (DCP1) (dipeptidyl carboxypeptidase 1). Nucleic Acids Res. 1992;20(6):1433.

35. Myerson SG, Hemingway H, Budget R, Martin J, Humphries S, Montgomery H. Human angiotensin I-converting enzyme gene and endurance performance. J Appl Physiol. 1999;87(4):1313-6.

36. Hruskovicova H, Dzurenkova D, Selingerova M, Bohus B, Timkanicova B, Kovacs $L$. The angiotensin converting enzyme I/D polymorphism in long distance runners. J Sports Med Physical Fitness. 2006;46(3):509-13.

37. Folland J, Leach B, Little T, Hawker K, Myerson S, Montgomery H, et al. Angiotensin-converting enzyme genotype affects the response of human skeletal muscle to functional overload. Exp Physiol. 2000;85(5):575-9.

38. Maestu J, Latt E, Raask T, Sak K, Laas K, Jurimae J, et al. Ace I/D polymorphism is associated with habitual physical activity in pubertal boys. J Physiol Sci. 2013;63(6):427-34.

39. Winnicki M, Accurso V, Hoffmann M, Pawlowski R, Dorigatti F, Santonastaso $M$, et al. Physical activity and angiotensin-converting enzyme gene polymorphism in mild hypertensives. Am J Med Genet A. 2004;125A(1):3844.

40. Fuentes RM, Perola M, Nissinen A, Tuomilehto J. ACE gene and physical activity, blood pressure, and hypertension: a population study in Finland2002 2002-06-01 00:00:00. 2508-12 p.

41. Knab AM, Bowen RS, Hamilton AT, Gulledge AA, Lightfoot JT. Altered dopaminergic profiles: implications for the regulation of voluntary physical activity. Behav Brain Res. 2009;204(1):147-52

42. Park YM, Kanaley JA, Padilla J, Zidon T, Welly RJ, Will MJ, et al. Effects of intrinsic aerobic capacity and ovariectomy on voluntary wheel running and nucleus accumbens dopamine receptor gene expression. Physiol Behav. 2016:164(Pt A):383-9.

43. Friend DM, Devarakonda K, O'Neal TJ, Skirzewski M, Papazoglou I, Kaplan AR, et al. Basal ganglia dysfunction contributes to physical inactivity in obesity. Cell Metab. 2017;25(2):312-21.

44. Sabol SZ, Hu S, Hamer D. A functional polymorphism in the monoamine oxidase a gene promoter. Hum Genet. 1998;103(3):273-9.

45. Shih JC, Thompson RF. Monoamine oxidase in neuropsychiatry and behavior. Am J Hum Genet 1999:65(3):593-8.

46. Huang YY, Cate SP, Battistuzzi C, Oquendo MA, Brent D, Mann JJ. An association between a functional polymorphism in the monoamine oxidase a gene promoter, impulsive traits and early abuse experiences. Neuropsychopharmacology. 2004:29(8):1498-505.

47. Deckert J, Catalano M, Syagailo W, Bosi M, Okladnova O, Di Bella D, et al. Excess of high activity monoamine oxidase a gene promoter alleles in female patients with panic disorder. Hum Mol Genet. 1999;8(4):621-4.

48. Jenkins TA, Mendelsohn FAO, Chai SY. Angiotensin-converting enzyme modulates dopamine turnover in the striatum. J Neurochem. 1997;68(3):1304-11.

49. Nyberg F, Terenius L. Degradation of Neuropeptides In: Henriksen JH, editor Degradation of Bioactive Substances: Physiology and Pathophysiology Boca Raton, Florida: CRC Press, Inc; 1991. p. 189-200.

50. Labandeira-Garcia JL, Rodriguez-Pallares J, Rodriguez-Perez Al, Garrido-Gil P, Villar-Cheda B, Valenzuela R, et al. Brain angiotensin and dopaminergic degeneration: relevance to Parkinson's disease. Am J Neurodegenerative Dis. 2012;1(3):226-44.

51. Kikuchi N, Yoshida S, Min SK, Lee K, Sakamaki-Sunaga M, Okamoto T, et al. The ACTN3 R577X genotype is associated with muscle function in a Japanese population. Appl Physiol Nutr Metabol. 2015;40(4):316-22.

52. Yang N, MacArthur DG, Wolde B, Onywera VO, Boit MK, Lau SY, et al. The ACTN3 R577X polymorphism in east and west African athletes. Med Sci Sports Exerc. 2007;39(11):1985-8.

53. Barley J, Blackwood A, Carter ND, Crews DE, Cruickshank JK, Jeffery S, et al. Angiotensin converting enzyme insertion/deletion polymorphism: association with ethnic origin. J Hypertens. 1994:12(8):955-7.

54. Mathew J, Basheeruddin K, Prabhakar S. Differences in frequency of the deletion polymorphism of the angiotensin-converting enzyme gene in different ethnic groups. Angiology. 2001;52(6):375-9. 
55. Bohn M, Berge KE, Bakken A, Erikssen J, Berg K. Insertion/deletion (I/D) polymorphism at the locus for angiotensin l-converting enzyme and myocardial infarction. Clin Genet. 1993;44(6):292-7.

56. Tronvik E, Stovner LJ, Bovim G, White LR, Gladwin AJ, Owen K, et al. Angiotensin-converting enzyme gene insertion/deletion polymorphism in migraine patients. BMC Neurol. 2008;8:4.

57. Shanmugam V, Sell KW, Saha BK. Mistyping ACE heterozygotes. PCR Methods Applications. 1993;3(2):120-1.

58. Gordish-Dressman H, Devaney JM. Statistical and methodological considerations in exercise genomics. Exercise Genomics: Springer; 2011. p. 23-43.

59. Cho J, Lee I, Kang H. ACTN3 gene and Susceptibility to sarcopenia and osteoporotic status in older Korean adults. Biomed Res Int. 2017;2017: 4239648.

60. Erskine RM, Williams AG, Jones DA, Stewart CE, Degens $H$. The individual and combined influence of ACE and ACTN3 genotypes on muscle phenotypes before and after strength training. Scand J Med Sci Sports. 2014:24(4):642-8.

61. Viken H, Aspvik NP, Ingebrigtsen JE, Zisko N, Wisloff U, Stensvold D. Correlates of objectively measured physical activity among Norwegian older adults: the generation 100 study. J Aging Phys Act. 2016;24(2): 369-75.

62. Leblanc A, Pescatello LS, Taylor BA, Capizzi JA, Clarkson PM, Michael White $C$, et al. Relationships between physical activity and muscular strength among healthy adults across the lifespan. SpringerPlus. 2015;4:557.

63. Rojer AGM, Reijnierse EM, Trappenburg MC, van Lummel RC, Niessen M, van Schooten KS, et al. Instrumented assessment of physical activity is associated with muscle function but not with muscle mass in a general population. J Aging Health. 2018;30(9):1462-81.

64. Gomes M, Figueiredo D, Teixeira L, Poveda V, Paúl C, Santos-Silva A, et al. Physical inactivity among older adults across Europe based on the SHARE database. Age Ageing. 2017;46(1):71-7.

65. Fowler JS, Alia-Klein N, Kriplani A, Logan J, Williams B, Zhu W, et al. Evidence that brain MAO a activity does not correspond to MAO a genotype in healthy male subjects. Biol Psychiatry. 2007:62(4):355-8.

66. Bauman AE, Reis RS, Sallis JF, Wells JC, Loos RJ, Martin BW. Correlates of physical activity: why are some people physically active and others not? Lancet. 2012;380(9838):258-71.

67. Lubs L, Peplies J, Drell C, Bammann K. Cross-sectional and longitudinal factors influencing physical activity of 65 to 75 -year-olds: a pan European cohort study based on the survey of health, ageing and retirement in Europe (SHARE). BMC Geriatr. 2018;18(1):94.

68. Wichstrom L, von Soest T, Kvalem IL. Predictors of growth and decline in leisure time physical activity from adolescence to adulthood. Health Psychol. 2013;32(7):775-84.

69. Prince SA, Adamo KB, Hamel ME, Hardt J, Connor Gorber S, Tremblay M. A comparison of direct versus self-report measures for assessing physical. activity in adults: a systematic review. Int J Behav Nutr Phys Activity. 2008;5: 56.

70. Bretthauer M, Gondal G, Larsen K, Carlsen E, Eide TJ, Grotmol T, et al. Design, organization and management of a controlled population screening study for detection of colorectal neoplasia: attendance rates in the NORCCAP study (Norwegian colorectal Cancer prevention). Scand J Gastroenterol. 2002:37(5):568-73.

71. Marchini J, Cardon LR, Phillips MS, Donnelly P. The effects of human population structure on large genetic association studies. Nat Genet. 2004;36(5):512-7.

72. Piirtola M, Kaprio J, Waller K, Heikkila K, Koskenvuo M, Svedberg P, et al. Leisure-time physical inactivity and association with body mass index: a Finnish twin study with a 35-year follow-up. Int J Epidemiol. 2016.

73. Ekelund U, Brage S, Besson H, Sharp S, Wareham NJ. Time spent being sedentary and weight gain in healthy adults: reverse or bidirectional causality? Am J Clin Nutr. 2008;88(3):612-7.

74. Metcalf BS, Hosking J, Jeffery AN, Voss LD, Henley W, Wilkin TJ. Fatness leads to inactivity, but inactivity does not lead to fatness: a longitudinal study in children (EarlyBird 45). Arch Dis Child. 2011;96(10):942-7.

75. Skjelbred CF, Saebo M, Wallin H, Nexo BA, Hagen PC, Lothe IM, et al. Polymorphisms of the XRCC1, XRCC3 and XPD genes and risk of colorectal adenoma and carcinoma, in a Norwegian cohort: a case control study. BMC Cancer. 2006;6:67.
76. Clinical Trials. NORCCAP: Norwegian Colorectal Cancer Prevention Trial: U.S. National Library of Medicine; [Available from: https://clinicaltrials.gov/show/ NCT00119912.

77. Ainsworth BE, Haskell WL, Leon AS, Jacobs DR Jr, Montoye HJ, Sallis JF, et al. Compendium of physical activities: classification of energy costs of human physical activities. Med Sci Sports Exerc. 1993;25(1):71-80.

78. Ainsworth BE, Haskell WL, Herrmann SD, Meckes N, Bassett DR Jr, TudorLocke C, et al. 2011 compendium of physical activities: a second update of codes and MET values. Med Sci Sports Exerc. 2011;43(8):1575-81.

79. Garber CE, Blissmer B, Deschenes MR, Franklin BA, Lamonte MJ, Lee IM, et al. American College of Sports Medicine position stand. Quantity and quality of exercise for developing and maintaining cardiorespiratory, musculoskeletal, and neuromotor fitness in apparently healthy adults: guidance for prescribing exercise. Med Sci Sports Exerc. 2011;43(7):1334-59.

80. Miller SA, Dykes DD, Polesky HF. A simple salting out procedure for extracting DNA from human nucleated cells. Nucleic Acids Res. 1988;16(3): 1215.

\section{Publisher's Note}

Springer Nature remains neutral with regard to jurisdictional claims in published maps and institutional affiliations.
Ready to submit your research? Choose BMC and benefit from:

- fast, convenient online submission

- thorough peer review by experienced researchers in your field

- rapid publication on acceptance

- support for research data, including large and complex data types

- gold Open Access which fosters wider collaboration and increased citations

- maximum visibility for your research: over $100 \mathrm{M}$ website views per year

At BMC, research is always in progress.

Learn more biomedcentral.com/submissions 